\title{
Öğrencilerin Enerji İçeceği Tüketim Bilincinin ve Alışkanlıklarının Araştırılmasında Bir Meslek Yüksekokulu Örneği
}

\author{
Fatma Çelik Kayapınar ${ }^{1}$ İlknur Özdemir ${ }^{2}$ \\ ${ }^{I}$ Mehmet Akif Ersoy Üniversitesi, Beden Eğitimi ve Spor Yüksekokulu, Burdur, Türkiye \\ ${ }^{2}$ Pamukkale Üniversitesi Acıpayam Meslek Yüksekokulu, Denizli Türkiye \\ E-mail: (nurozdemir@pau.edu.tr)
}

\begin{abstract}
Özet
Çalışmanın amacı yükseköğretim düzeyindeki öğrencilerin enerji içecekleri hakkında bilgi düzeylerini ve tüketim alışkanlıklarını belirlemektir. Araştırma evrenini Honaz Meslek Yüksekokulu öğrencileri oluştururken örneklemini anketi doldurmayı kabul eden toplam 100 öğrenci (58 kadın ve 42 erkek) oluşturmuştur. Araştırmada öğrencilere demografik özellikleri, enerji içecekleri hakkındaki bilgileri ve tüketim alışkanlıkları, sağlık üzerindeki etkileri hakkında sorular yöneltilmiştir. Yaşları 18-24 yıl arasında değişen öğrencilerden elde edilen verilere yüzde frekans dağılımı yapılmıştır. Katılımcıların \%55 oranında enerji içeceği tükettiği, \%73'ünü enerji içeceği hakkında bilgi sahibi olmadıklarını, enerji içeceklerinin şeker (\%66) ve kafein (\%44) içerdiğini, enerji içeceklerinin kalp için tehlikeli olduğunu (\%62), uyku saatini azalttığını (\%46) ifade etmişlerdir.

Sonuç olarak; ön lisans öğrencilerinin \%55'i tadını sevdikleri için enerji içeceği tükettikleri ve enerji içeceklerinin bileşenleri ve bu bileşenlerin sağlık açısından ortaya çıkardığı riskleri bilmedikleri saptanmıştır. Öğrencilerin enerji içeceği tüketimi ve etkileri konusunda görsel medya ve yazılı kaynaklar aracıllğı ile bilgi ve bilinç düzeyinin artırılması gerekmektedir.
\end{abstract}

Anahtar Kelimeler: Enerji içeceği, tüketim bilinci, bilgi düzeyleri

\begin{abstract}
The study aims to determine the energy drink knowledge levels and consumption habits of the students of higher education institution. The universe of the study consisted of the Honaz Vocational College agreeing to participate in our study. The sampling of the study consisted of 100 students (58 female, 42 male) who agreed to fill in the questionnaire. The demographic characteristics of the students, knowledge on energy drinks, consumption habits, the effects of the energy drinks on health were asked to the students. The percentage frequency distribution was made by using the data from the students whose mean age was 18-24. It was determined that $55 \%$ of them consumed energy drinks, $73 \%$ of them stated they did not have knowledge on energy drinks, $66 \%$ stated there was sugar, $44 \%$ stated there was caffeine in them, $62 \%$ of them stated they were dangerous for heart, $46 \%$ of them stated they decreased the sleeping hours.

As a conclusion: It was observed that $55 \%$ of the undergraduate students consumed energy drinks because they liked the taste and did not know the ingredients and the risks for health. The knowledge and conscious levels of the students about energy drink consumption and it is effects must be increased by visual and written media devices.
\end{abstract}

Key Words: Energy drink, conscious of consumption, knowledge levels. 


\section{Giriş}

Enerji içecekleri dünyaya Amerikalı bilim adamı Dr. Enuf tarafindan 1949 yılında tanıtılmış vitamin ve şeker ile desteklenerek şekerli sodalara alternatif olarak sunulmuştur. Bunu takiben 1960 yılında Asya ve Avrupa da kullanılmaya başlanmıştır (Reissig ve ark, 2009). Dünyada yaygın kullanımı 1980'li yıllara rastlamakla birlikte Türkiye'de satışa sürüm yılı 1990'lı yıllara denk gelmektedir. Türkiye'de yaklaşı 25 farklı marka enerji içeceği satıldığı, küçük partiler halinde de daha birçok markanın raflarda yerini aldığı, toplam marka sayısının 42'ye ulaştığı belirtilmektedir (Dikici ve ark, 2012).

Enerji içeceği, kafein içeren taurin, glukoronolakton, inositol gibi maddeleri, karbonhidrat, aminoasitler, vitaminler, mineraller ve aromalandırılmış alkolsüz içeceklerdir (Gıda Tarım ve Hayvancılık Bakanlığı, 2014). Enerji içecekleri genel olarak su, karbonhidrat (glikoz, maltodekstrin, sükroz), düşük miktarda $\mathrm{B}$ komplex vitaminleri (tiamin, riboflavin, niasin, inositol, pantotenik asit, siyanokobalamin), vitamin C, mineral, elektrolit (sodyum, potasyum, fosfor), bitki özütleri (guarana, yerba mate, ginseng, ginko biloba), uyarıcı madde (kafein, green tea, synephrine, yohimbin, tyramine, vinpocetine), glukoronolakton, taurin, L-karnitin içermektedir (Zucconi ve ark, 2013; Ghosh, 2015). Enerji içeceklerinin temel aktif bileşeni $225 \mathrm{gr}$ da $80-141 \mathrm{mg}$ kafein ve genellikle yüksek miktarda (yaklaşık \% 9-10) karbonhidratlardır (Ghosh, 2015).

Enerji içeceklerinin özel bir formu olan enerji shotlar ise; az miktarda şeker içeren düşük kalorili, 60-90 ml hacminde küçük kutularda satışa sunulan konsantre içeceklerdir (Schubert ve ark, 2013). Enerji içecekleri ve enerji shotlar egzersiz öncesi ve egzersiz sırasında ihtiyaç duyulan enerjiyi sağlarken dayanıklılık seviyesini arttırmak, özellikle sınav zamanlarında ortaya çıkan uykusuzluğu ekarte edip vücudu uyanık şekilde ayakta tutmak ya da alkolle birlikte ruhsal durumu yükseltmek için tüketilir. Uyanıklığın artırılması etkisi enerji içeceklerinde bulunan kafeinin adenozin benzeyen kimyasal yapısından kaynaklanmaktadır. Kafein adenozin reseptörüne bağlanarak sinir hücrelerinin etkinliğini arttırmakta ve buna bağlı olarak adenosinin uyku getiren etkisi kaybolmaktadır. Ayrıca kafein güçlü bir kardiovasküler uyarandır ve epinefrin salgısını arttırarak mental ve fiziksel performansın artmasını sağlar. Kafein alımı enerji artışı ile birlikte daha iyi performansın ortaya çıkmasını dayanıklılık, mood ve uyanıklık seviyesininde artmasını sağlar. Ek olarak yiyecek alımını azaltarak lipolize imkan sağlar (Yunusa ve Ahmed 2011). Roberts ve arkadaşları (2008) çalışmasında 28 gün kalorisi olmayan enerji içeceğini (336ml/gün) olarak vermişler ve yağ kütlesinin kontol grubu ile karşılaştırıldığında anlamlı şekilde azaldığını bildirmişlerdir. Stout ve arkadaşları (2008) 10 hafta boyunca egzersizden 15 dakika önce ve egzersizin olmadığ 1 günlerde istenildiği zaman alınan enerji içeceğinin vücut kompozisyonuna ve fitnes düzeyindeki değişimlere etkisini incelemişlerdir. Kontrol grubu ile karşılaştırıldığında enerji içeceği tüketen grupta yağ kütlesinin azalarak, aerobik kapasitenin ve tükenme zamanının arttı̆̆ını Scholey ve Kenndy (2003) $250 \mathrm{ml}$ enerji içeceğinin ( $37.5 \mathrm{~g}$ glikoz, 75 mg kafein, ginseng ve ginko biloba) ikincil bellek hafızası ve dikkat üzerinde olumlu etkileri olduğunu Alford ve arkadaşları (2001) yüksek satış oranına sahip bir enerji içeceğinin psikomotor performansı (reaksiyon süresi, konsantrasyon ve hafiza), kişisel uyanıklılığı ve bisiklet ergometresinde yapılan testlerde aerobik dayanıklılığı (kalp atım hızının \%65-75) ve aerobik performansı (maksimal hızı sürdürme) arttırdığını belirtmişlerdir. Worthley ve ark. (2010) $250 \mathrm{ml}$ (80 mg kafein, 1000mg taurin, $600 \mathrm{mg}$ glukoronolakton), şekeriz enerji içeceğinin alımından 1 saat süre sonra kan basıncı artışına, trombosit agregasyonu ve endotel yapı bozulmalarına sebep olduğunu Bedi ve ark, 2014) yüksek miktarda enerji içeceği tüketmenin tip2 diyabet ve obezite riskini arttırdığ1 Beaudoin ve ark (2012) insülin duyarlılığını azalttığını, Hasselkvist ve ark (2009) dental erezyonu arttırdığını, (Reyner ve Horne 2002) enerji içeceğinin sürüş performansını arttırdığını, Hoffman ve ark (2009) egzersiz sırasında reaksiyon performansını geliştirdiğini fakat anaerobik performansa etkisinin olmadığını, Ivy ve ark (2009) profosyonel 12 kadın-erkek bisiklet sporcusunda enerji içeceğinin dayanıklılık performansını arttırırken, tükenme zamanına etki etmediğini ayrıca Perez ve ark (2015) yaklaşık olarak $3 \mathrm{mg} / \mathrm{kg}$ oranında kafein içeren enerji içeceğinin bayan voleybolcularda fiziksel performansı 
arttırdığı bildirmişlerdir. $\mathrm{Bu}$ bulgulardan yola çıkarak enerji içeceklerinin antrenmanda fiziksel performansı ve bilişsel performansı arttırabileceği, kilo vermek için gerçekleştirilen kullanımlarda bazı ergojenik etkileri olabileceği gibi trombosit agregasyon ve endotel yapıda bozulmalara, kalp dolaşım sorunlarına, yüksek kan basıncına, insilün duyarlılığına neden olabileceği de söylenebilir. $\mathrm{Bu}$ sebeplerden dolayı enerji içeceği tüketirken günlük alınması gereken maksimum kafein miktarı da göz önünde bulundurulmalıdır. Enerji içeceğinin tüketim oranları ve etkileri ile ilgili literatürde çelişkili bulgular olmasından dolayı aşırı tüketimden kaçınılmalıdır.

$\mathrm{Bu}$ çalışmanın amacı, fazla enerji ihtiyacı hisseden öğrenciler, sporcular, uzun süre araç kullananlar ve alkolle kokteyl yaparak tüketenlerin ihtiyaçlarına hızla cevap verdiğine inandıkları için kullandıkları enerji içeceklerinin ön lisans öğrencileri arasında tüketim düzeyi, tüketim alışkanlıkları ve bilgi düzeylerinin belirlenmesidir.

\section{Materyal ve Metot}

Çalışma evrenini, 2015-2016 eğitim-öğretim yılında Pamukkale Üniversitesi Honaz Meslek Yüksekokulunda öğrenimlerine devam eden öğrenciler oluştururken araştırmanın örneklemini, 58 kadın ve 42 erkek olmak üzere toplam 100 öğrenci oluşturmuştur. Gönüllü öğrencilerden araştırmacılar tarafından hazırlanan anketi doldurmaları istenmiş̦tir. Durum saptamak üzere hazırlanan ankette öğrencilere Tablo 1 demografik bilgiler (yaş, yaşadıkları yer, anne-baba eğitim düzeyleri, mezun oldukları lise türü), Tablo 2 günlük yaşam alışkanlıkları (egzersiz yapma durumları, uyku alışkanlıkları, su dışında en çok tükettikleri içecek, alkol-sigara kullanma durumları) Tablo 3 enerji içeceği hakkındaki bilgi düzeyleri ve sağlık üzerine etkileri (enerji içeceği hakkında bilginiz var $\mathrm{m} ı$ var ise bilgiyi nereden aldıkları, enerji içeceği zararlı mıdır, içindekiler nelerdir, enerji içeceğinin sağlık üzerine etkileri) Tablo 4 enerji içeceği tüketim alışkanlıkları ve miktarı (enerji içeceği tüketir misiniz, günlük tüketim miktarı) Tablo 5 enerji içeceği tüketme-tüketmeme nedenlerini içeren sorular yöneltilmiştir. Anketten elde edilen veriler istatistik programına kodlanarak, \% (yüzde) ve frekans analizi uygulanmıştır. Elde edilen veriler bulgularda tablolar halinde sunulmuştur.

\section{BULGULAR}

Tablo1 incelendiğinde katılımcıların \%81'inin 18-20 yaş aralığında oldukları, \%30'unun arkadaşları ile \%27'sinin yurtta kalmakta iken anne eğitim düzeylerinin \%52 ilkokul, \%28'i ortaokul, baba eğitim düzeyleri \%46 ilkokul, \%23 ortaokul olduğu belirlenmiştir. Katılımcıların mezun oldukları okul türü ise $\% 51$ oranında meslek lisesidir.

Tablo:1 Katıllmcıların demografik özelliklerinin yüzde ve frekans dağıllımları

\begin{tabular}{llll}
\hline \multirow{3}{*}{ Yaş (yıl) aralıkları } & Veriler & $\mathrm{N}$ & Frekans\% \\
\cline { 2 - 4 } & $18-20$ & 81 & 81 \\
& $21-23$ & 15 & 15 \\
Yaşadı̆̆ı yer & 24 ve üzeri & 4 & 4 \\
\cline { 2 - 4 } & Aile ve kardeşlerle & 20 & 20 \\
& Arkadaşlarla & 30 & 30 \\
& Yurtta & 27 & 27 \\
& Pansiyon & 16 & 16 \\
& Tek başına & 7 & 7 \\
\cline { 2 - 4 } & Okur Yazar & 3 & 3 \\
& İlkokul & 52 & 52
\end{tabular}




\begin{tabular}{llll} 
Anne eğitim durumu & Ortaokul & 28 & 28 \\
& Lise & 12 & 12 \\
& Ön lisans & 1 & 1 \\
& Lisans & 4 & 4 \\
\cline { 2 - 4 } Baba eğitim durumu & Okur Yazar & 1 & 1 \\
& İlkokul & 46 & 46 \\
& Ortaokul & 23 & 23 \\
& Lise & 20 & 20 \\
& Ön lisans & 5 & 5 \\
Mezun olunan okul türü & Lisans & 4 & 4 \\
\cline { 2 - 4 } & Anadolu Lisesi & 29 & 29 \\
& Meslek Lisesi & 51 & 51 \\
& Kolej & 1 & 1 \\
& Açik Lise & 1 & 1 \\
& Diğer & 18 & 18 \\
\hline
\end{tabular}

Tablo2 incelendiğinde katılımcıların \%56 oranında spor yaptıkları, uyku alışkanlıklarının \%59 oranında düzensiz olduğu, gün içerisinde su dışında en çok $\% 51$ oranında çay ve $\% 35$ kahve tükettikleri $\% 55$ oranında hiç sigara kullanmadıkları ve \%61 oranında hiç alkol kullandıkları belirlenmiştir.

Tablo:2 Katılımcıların günlük yaşam alışkanlıkları hakkındaki yüzde dağglım tablosu

\begin{tabular}{llll}
\hline \multirow{2}{*}{ Egzersiz yapar mısınız } & Veriler & $\mathrm{N}$ & Frekans\% \\
\cline { 2 - 4 } & Evet & 56 & 56 \\
\multirow{3}{*}{ Uyku alışkanlığınız } & Hayır & 44 & 44 \\
\cline { 2 - 4 } Su dışında en çok tüketilen içecek & Düzenli & 41 & 41 \\
& Düzensiz & 59 & 59 \\
\cline { 2 - 4 } & Çay & 51 & 51 \\
Sigara kullanım durumları & Kahve & 35 & 35 \\
& Gazlı içecek & 14 & 14 \\
\cline { 2 - 5 } & Kullanıyor & 37 & 37 \\
Alkol kullanım durumları & Kullanmıyor & 55 & 55 \\
& Eskiden Kullanmış & 8 & 8 \\
\cline { 2 - 5 } & Kullanıor & 28 & 28 \\
& Kullanmıyor & 61 & 61 \\
\hline
\end{tabular}

Tablo 3 incelendiğinde katılımcıların $\% 73$ oranında enerji içeceği hakkında bilgi sahibi olmadıkları, bilgi sahibi olanların \%14'ü görsel medyadan \%10'u yazılı kaynaklardan bilgi sahibi olduklarını,\%44 oranında enerji içeceklerinin zararlı olduğunu, enerji içeceklerinin içinde $\% 44$ oranında kafein, \%66 şeker, \%27 karbondioksit ve diğer gazlar, \%28 alkol, \%24 sitrik asit olduğunu belirtmişler ayrıca enerji içeceklerinin \%62 oranında kalp için tehlikeli olduğunu, \%46 oranında uyku saatini azalttığını, 
$\% 40$ oranında enerji sağladığı ve \%40 oranında sağlık için yararı olmadığını, \%26 oranında böbrekler için zararlı olduğunu belirtmişlerdir.

Tablo:3 Katıllmcıların enerji içecekleri hakkında bilgi düzeyleri ve sağllk üzerindeki etkileri ilgili yüzde ve frekans dağılımları tablosu

\begin{tabular}{|c|c|c|c|}
\hline \multirow{4}{*}{ Enerji içeceği hakkında bilginiz var mı? } & Veriler & $\mathrm{N}$ & Frekans $\%$ \\
\hline & Evet & 32 & 32 \\
\hline & Hayır & 68 & 68 \\
\hline & Okul & 1 & 1 \\
\hline \multirow{2}{*}{$\begin{array}{l}\text { Enerji içeceği hakkında bilgiyi nereden } \\
\text { aldınız? }\end{array}$} & Görsel medya & 14 & 14 \\
\hline & Arkadaş & 6 & 6 \\
\hline \multirow{7}{*}{ Enerji içeceği zararlı mıdır? } & Yazılı kaynaklar & 10 & 10 \\
\hline & Diğger & 1 & 1 \\
\hline & Evet & 44 & 44 \\
\hline & Hayır & 30 & 30 \\
\hline & Fikrim yok & 26 & 26 \\
\hline & Kafein & 47 & 47 \\
\hline & Şeker & 66 & 66 \\
\hline \multirow{6}{*}{ Enerji içeceğinin içerisindekiler nelerdir? } & Tuz ve mineral & 8 & 8 \\
\hline & Vitamin & 9 & 9 \\
\hline & Karbondioksit ve diğer gazlar & 27 & 24 \\
\hline & Sitrik asit & 24 & 24 \\
\hline & Taurin & 11 & 11 \\
\hline & Protein & 9 & 9 \\
\hline \multirow{15}{*}{$\begin{array}{l}\text { Enerji içeceği sağlı üzerine etkisi } \\
\text { nelerdir? }\end{array}$} & Alkol & 28 & 28 \\
\hline & Nikotin & 18 & 18 \\
\hline & Kalp için tehlikelidir. & 62 & 62 \\
\hline & Uyku saatini azaltır. & 46 & 46 \\
\hline & Enerji sağlar. & 40 & 40 \\
\hline & Mineral kaynağıdır. & 11 & 11 \\
\hline & Su kaynağıdır. & 9 & 9 \\
\hline & Vitamin kaynağıdır. & 8 & 8 \\
\hline & Sağlığa yararlı etkisi yoktur. & 40 & 40 \\
\hline & Böbreklerde olumsuz etkisi vardır. & 26 & 26 \\
\hline & Obeziteye sebep olur. & 18 & 18 \\
\hline & Depresyona sebep olur. & 13 & 13 \\
\hline & İnsülin direnci oluşturur. & 16 & 16 \\
\hline & Diş problemlerine sebep olur. & 16 & 16 \\
\hline & Mide ünserine sebep olur. & 17 & 17 \\
\hline
\end{tabular}

Tablo 4 incelendiğinde katılımcıları $\% 55$ 'i enerji içeceği tükettiğini ve günlük tüketim miktarının $\% 27$ 'si 200 ml'den az \%18'i $250 \mathrm{ml}$ ve daha fazla olduğunu belirtmişlerdir. 
Tablo:4 Katılımcıların enerji içeceği tüketim alıskanlıkları ve günlük tüketim miktarı ilgili yüzde ve frekans dağılım tablosu

\begin{tabular}{llll}
\hline & Veriler & $\mathrm{N}$ & Frekans\% \\
\cline { 2 - 4 } Enerji içeceği tüketir misiniz? & Evet & 55 & 55 \\
& Hayır & 45 & 45 \\
\cline { 2 - 4 } & $200 \mathrm{ml}$ den az & 27 & 27 \\
Günlük ne kadar tüketiyorsunuz? & $250 \mathrm{ml}$ den fazla & 18 & 18 \\
& $500 \mathrm{ml}$ & 4 & 4 \\
& $11 \mathrm{tt}$ & 1 & 1 \\
& $11 \mathrm{t}$ den fazla & 2 & 2 \\
\hline
\end{tabular}

Tablo 5 incelendiğinde; enerji içeceği tüketen katılımcıların \%29'u tadını sevdikleri için, \%13'ü alkolle karıştırdıkları için enerji içeceği tüketirken enerji içeceği tüketmeyenlerin \%35'i özel bir nedeni olmadığını, \%11'i sağlıksız olduğunu düşündükleri için enerji içeceği tüketmediklerini bildirmişlerdir.

Tablo:5 Katılımcıların enerji içeceği tüketme-tüketmeme nedenleri yüzde ve frekans dă̆llım tablosu

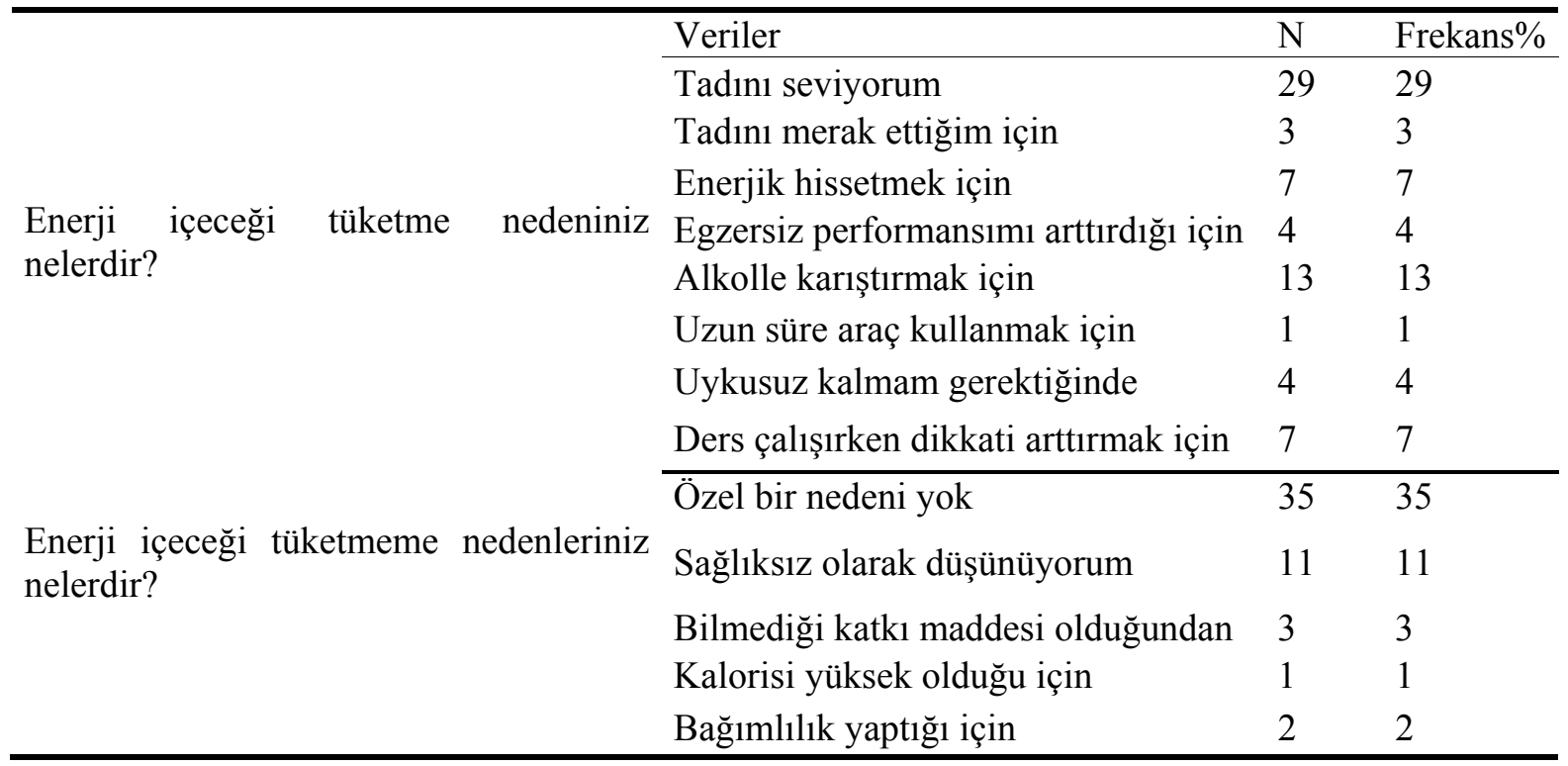

\section{Tartışma ve Sonuç}

$\mathrm{Bu}$ çalışma Honaz Meslek Yüksekokulu öğrencilerinin enerji içecekleri hakkındaki bilgi düzeyleri ve tüketim alışkanlıklarını belirlemek amacı yapılmıştır. Enerji içeceklerinin pazarlanmasında temel satış stratejileri bu içeceklerin performansı (Malinauskas ve ark., 2007), dayanıklılı̆̆ $\operatorname{arttırd}_{\breve{g} 1}$ (Alford ve ark., 2001; Ivy ve ark., 2009), konsantrasyonu (Alford ve ark., 2001) ve ruhsal durumu yükselttiği (Smit ve Rogers, 2000; Ivy ve ark, 2009) iddaalarıdır. Enerji içecek firmaları fazla enerji ihtiyacı hisseden öğrenciler (Malinauskas ve ark., 2007; Oteri, 2007), sporcular, uzun süre araç kullananlar ve alkolle kokteyl yaparak tüketenlerin (Oteri, 2007), ihtiyaçlarına hızla cevap verdiğine inandıran sayısız reklam ve satış promosyonları yapmaktadırlar.

Çalışmada verilerden elde edilen bulgularına göre katılımcıların demografik özellikleri incelendiğinde (Tablo 1) büyük çoğunluğunun meslek liselerinden mezun oldukları, anne ve baba 

BİR MESLEK YÜKSEKOKULU ÖRNEĞİ

eğitim durumlarının sırasıyla $(\% 52, \% 46)$ ilkokul ve $(\% 28, \% 23)$ ortaokul olduğu ve öğrencilerin \%30'u arkadaşları ile \%27 yurtta kaldıkları tespit edilmiştir. Katılımcıların \%55'i enerji içeceği tüketmekte, tüketenlerin \%27'si $200 \mathrm{ml}$ den az \%18'inin $200 \mathrm{ml}$ den fazla oranda tüketim yaptığ1 belirlenmiştir. Tüketim nedenleri \%29 oranda tadını sevmeleri, \%13 oranında alkolle karıştırmak için, \%7'si enerjik hissettirdiği için, \%4'ü egzersiz performansını artırdığı, \%7'si ders çalışırken dikkati artırdığ için tükettiğini belirtmişlerdir. Literatürde incelendiğinde; 2011 Avrupa Gıda Güvenliği Kurumu (European Food Safety Authority) komisyon raporlarına göre 16 Avrupa birliği üyesi ülke verilerine göre adölesanların (10-18 yaş) \%68'i, yetişkinlerin \%30'u ve çocukların $(<10$ yaş) \%18'i enerji içeceği tüketmektedir. Malinauskas ve arkadaşlarının yaptıkları çalışmada (2007) üniversite öğrencileri arasında enerji içeceği tüketim oranını 51\% olarak rapor edilmiştir. Bu oran yapılan çalışmada elde edilen oran (\%55) ile benzerdir. Yapılan çalışmadan farklı olarak enerji içeceği tüketim oranları Froiland ve ark., (2004) çalışmalarda 73\%, Kristiansen ve ark., (2005) tarafindan 86.7\% olarak rapor edilmiştir. Bu farklılıklar, çalışmaya katılan grupların farklı kültürel özelliklere sahip olma, ekonomik düzey ve farklı coğrafi koşullardan kaynaklanabilir. Malinauskas ve arkadaşlarının (2007) çalışmasında tüketim nedenleri enerji düzeyini arttırdığı için (\%65), parti ve eğlence ortamında alkolle tüketmek için (\%57) olduğunu belirtmişlerdir. Hıdıroğlu ve ark., (2013) yaptıkları çalışmada ise; en az bir kez enerji içeceği tükettiğini belirten 127 öğrencinin $(\% 32,6)$ enerji içeceği tüketme nedeni bilişsel performansı ve fiziksel performansı arttırmak olarak belirtmişlerdir. Duchan ve arkadaşları (2010) ise firmaların enerji artırır iddialarının yanı sıra içindeki maddelerin ergojenik etkisinden, kafein ve diğer bileșenlerinden kaynaklandığı bildirmișlerdir. Yapılan çalışmada ise literetürün aksine $\% 7$ oranında enerjik hissetmek belirtilirken $\% 29$ oranında tadını sevmek olarak belirtmişlerdir. Bu sebeplerin farklı oluşu ülkemizde dengeli ve düzenli beslenmeden daha çok damak tadına göre beslenme yapıldığını düşündürmektedir. Oteri ve arkadaşlarının çalışmalarında (2007) üniversite öğrencileri ve sporcular tarafından bilişsel ve sportif performans artış1 sağladığı için tüketildiğini ifade etmişlerdir. Yapılan çalışmada ise farklı olarak \%4 oranında egzersiz performansını arttırmak için olduğu belirlenmiş ancak oldukça düşüktür.

Çalışmaya katılan öğrencilerin \%68 oranında enerji içeceği hakkında bilgisi olmadığı, bilgisi olan öğrencilerin bilgi kaynaklarının \%14'ünün görsel medya, \%10'unun yazılı kaynak, \%6'sının arkadaş çevresinden, \%1'inin okul ve farklı kaynaklar olduğunu belirtmişlerdir. Öğrencilerin \%44'ü enerji içeceğinin zararlı olduğunu, \% 30'u zararsız olduğu ve \%26'sının konu hakkında fikri olmadığ belirlenmiştir. Enerji içeceklerinin içindeki maddeler hakkındaki bilgi düzeyleri konusunda araştırma bulguları $\% 47$ oranında kafein, \%66 oranında şeker, \%24 sitrik asit , \%27 karbondioksit ve diğer gazlar, $\% 9$ vitamin, $\% 8$ mineral, , \%9 protein, $\% 11$ taurin, $\% 28$ alkol olduğunu bildirmişlerdir. Literatürde, enerji içeceklerinin çoğu düşük oranlarda vitamin (thiamin, riboflavin, niacin, vitamin B6, B12, pantotenik asit, vitamin c) ve elektrolit (sodyum, potasyum, fosfor) içerir. Ayrica enerji içeceklerinin içerisinde bulunan bu maddeler besin desteklerinin yoğunluğunu arttırabilir, egzersiz sırasında ergojenik destek olarak performans arttırdığına dair bazı çalışmalar vardır (Rodriguez, 2009; Kreider ve ark., 2010). Enerji içeceklerinin bileşiminde bulunan diğer maddeler (taurin, ginko biloba, L-tyrosine, citocoline, 5Hydroxy-L-Tryptophan) uyarıcilar (kafein, guarana, green tea, synephrine, yerba mate, yohimbine, tyramine, vinpocetine) ve ergojenik besinler (panax ginseng, L-karnitin, Dribose, $\beta$-alanine, inositol, citrulline, quercetin) olarak belirtilmiştir (Rodriguez, 2009; Kreider ve ark., 2010). Alkol dışında belirtilen bileşenlerin her birisi enerji içeceğinin türü ve boyutuna göre farklı oranlarda enerji içeceklerinin içinde bulunmaktadır. Alkol bu içeceklerin içindekiler kısmında listelenmemektedir. Yapılan çalışmada enerji içeceklerinin içindeki maddeler hakkında katılımcıların verdikleri cevaplar, bilgi düzeylerinin yetersiz olduğunu göstermektedir. Yapılan çalışma verilerine paralel olarak Hıdıroğlu ve ark. (2013) tarafından yapılan benzer bir çalışmada tıp fakültesi öğrencilerinin enerji içecekleri hakkında bilgi düzeyinin yetersiz olduğu belirtilmiştir.

Enerji içeceklerinin temel aktif bileşeni $80-141 \mathrm{mg} / 225$ gr kafein ve genellikle yüksek miktarda (yaklaşık \% 9-10) karbonhidratlardır (Ghosh, 2015). Enerji içeceklerinin bilişsel uyarıcı etkisi kafeinden kaynaklanmakta (Smit ve ark., 2004) iken yüksek şeker içeriği nedeni ile (\%18) reaksiyon süresini geliştirmediği uyku süresini azalttığını (Loyacano, 2000) dahası kafein ve taurin 
kombinasyonunun kısa süreli hafizaya etkisi olmadığı (Bichler ve ark., 2006) bunlara rağmen düşük dozlarda kafein alımının (12,5-50 mg) genç yetişkinlerde bilişsel performansı geliştirdiği ve ruhsal durumu yükselttiği (Smit ve Rogers, 2000) ve 200mg düzeyinde bilişsel hızı uyanıklığı geliştirdiği belirtilmektedir (Dasey, 2007). Enerji içeceklerindeki kafein miktarı, kafeinin bilişsel performans arttırıcı işlevi için gereken miktarının kolayca üzerine çıkabilmektedir (Kohler ve ark., 2006). Özellikle 450-670 gr miktarında kutularda ise bu daha hızlı olmaktadır. Yapılan araştırmadaki tüketim oranı bu seviyelerin daha altında tespit edilmiş olup yüksek düzeyde bilişsel performansı, uyanıklığı artırıcı miktarda tüketildiği söylenebilir ancak gün içerisinde tükettikleri diğer kafeinli içecek oranlarını tespit edilemediğinden bu konuda daha net ifadelerde bulunulmasını engellemektedir. Enerji içeceklerinin orta düzeyde tüketimi sağlı açısından yarar sağlarken aşırı miktarda kafein içeren içeceklerin tüketimi endişe, huzursuzluk, mide problemleri, kas seyirmesi (Bedi ve ark, 2014), baş ağrısına (Espinosa ve Sobrino 2015) dehidrasyona, nöbetler geçirilmesine, enerji içeceği tüketimi takiben kalp durmasına (Avcı ve ark., 2013), içeceklerin içinde bulunan asitten ve şekerden kaynaklanan diş minesi erezyonuna neden olur (Hasselkvist, 2009; Shelon ve ark, 2013). Çalışmaya katılan öğrenciler gün içerisinde su dişında $\% 51$ çay, $\% 35$ kahve, $\% 14$ gazlı içecek tükettiğini bildirmişlerdir. Bu içeceklerin içerisinde de kafein olduğu düşünülürse yüksek oranda enerji içeceğinin yanında diğer içeceklerden de alınan kafeinle bu olumsuz etkilerin ortaya çıkma riski artabilir.

Enerji içeceklerinin sağlık üzerindeki etkileri (Tablo 3) hakkındaki soruya \%62 kalp için tehlikeli, \%46 uyku süresini azaltır, \%26 böbreklerde olumsuz etki yaptığını, \%18 obeziteye sebep olduğunu belirtirlerken, $\% 16$ insülin direnci oluşturduğu, $\% 17$ mide ülserine, $\% 16$ diş problemi $\% 13$ depresyona sebep olduğunu belirtmişlerdir. Literatür incelendiğinde, Berger ve Alford (2009) Avustuya'da 2007 yılında yoğun fiziksel aktivite yaparken 7-8 kutu enerji içeceği tüketen bir erkeğin kalp krizi geçirerek öldüğünü, 28 yaşındaki motor sporcusunun, 5 saat süresince her biri $80 \mathrm{mg}$ kafein içeren 8 kutu enerji içeceği tüketimi sonucunda aşırı kafein tüketiminin neden olduğu kalp durması sonucunda yarış sırasında öldügü bildirilmiştir (Anderson ve Horne, 2006). Bir başka örnek olay ise Amerika'da meydana gelmiştir. Basketbol maçı öncesinde 3 kutu $250 \mathrm{ml}$ enerji içeceği tüketen 28 yaşındaki bir erkek 30 dakika maçta oynadıktan sonra bilinç kaybı ile birlikte ani kalp durması sonucunda öldüğü bildirilmiştir (Avcı ve ark., 2013). Bu olgular kafein tüketim riskini daha açık ortaya koymakta ve tüketim dozunun doğru ayarlanması gerektiği düşünülmektedir. Enerji içeceklerinin tüketim miktarı önemlidir; aşırı tüketimlerin kafein içeriğinden dolayı kalp için tehlikeli olduğu (Anderson ve Horne, 2006), uyku saatini azalttı̆̆ (Riesenhuber, 2006), insülin direnci oluşturduğu (Lee ve ark., 2005), diş problemleri (Shelon ve ark., 2013) ve mide problemlerine ve kan basıncı problemlerine (Bichler ve ark., 2006) neden olduğu belirtilmiştir. Baum ve Weiss (2001) daha önce dayanıklılık egzersizleri yapan antrenmanlı 13 kişiyi 3 farklı gruba ayırmış ve farklı zamanda (içecek içmeden önce, içecek içildikten 40 dakika sonra, egzersizden hemen önce ve egzersizden sonra toparlanma zamanında) elektrokardiyogram ile ölçümler yapmıştır. Gruplara Redbull, kafein içeren taurin içermeyen benzer bir içecek ve plasebo (kafein ve taurin içermeyen) içecek vermişlerdir. Sonuç olarak sadece Redbull içeceğini tüketen grupta kalp atım hacminin arttığ (Rebull tüketmeden önce $80 \pm 21 \mathrm{~mL}$, toparlanma periyodunda $98 \pm 26 \mathrm{~mL}$ ) bunun temel nedeninin Redbull bileşimindeki kafein ve taurinin kardiyak kasılma üzerine etkisinden kaynaklandığı belirtilmiştir. Enerji içeceği tüketimi ile birlikte kalp atım hacminde meydana gelen artış ile vücuda daha fazla oksijenli kan gönderilmekte bu durumda aerobik kapasitenin artmasını desteklemektedir. Diğer taraftan yüksek miktarlarda tüketilen enerji içecekleri kalbi aşırı düzeyde zorlamakta ve kalp krizi riskini arttırmaktadır. Yapılan çalışmada öğrencilerin enerji içeceklerinden kaynaklanabilecek sağlık riskleri ve içecekleri kalp üzerindeki etkileri hakkında yeterli düzeyde bilgi sahibi olmadıkları söylenebilir.

Öğrencilerin \%55'inin sigara kullanmadığı, \%37'sinin sigara içtiği ve \%8'inin eskiden kullandığı ayrıca \%28'inin alkol kullandığı, \%61 alkol kullanmadığ 1 ve \%11 eskiden kullandıklarını, \%56 oranında spor yaptıklarını ve $\% 59$ oranında uyku alışkanlıklarının düzensiz olduğu saptanmıştır. 

BİR MESLEK YÜKSEKOKULU ÖRNEĞİ

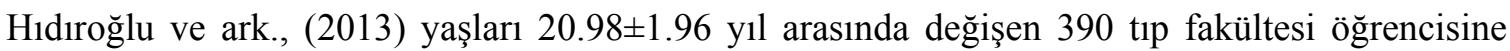
( $n=204$ kadın, n=186 erkek) enerji içeceği anketi uygulamış ve öğrencilerin \%13,3'ü düzenli olarak günde en az bir kez sigara içtiklerini, \%32,6 oranında alkol tükettiklerini, \%32,6'sının bir kez ve $\% 18,8$ birden fazla enerji içeceği tükettiğini, \%28,2'sinin enerji içeceği ile sporcu içeceğinin benzer olduğunu belirtmişlerdir. Literatürde yapılan araştırmalarda enerji içeceği tüketenlerin büyük çoğunluğunun genç yetişkinler ve üniversite öğrencileri olması alkolle enerji içeceğini karıştırarak kokteyl şeklinde (Arria ve ark., 2011) ya da sigara, mariuana gibi maddelerle birlikte tüketimden kaynaklanan bilinçsiz karar vermenin, fazla tüketimden kaynaklı zehirlenmenin, alkollü araç kullanımının, kavga etmek ve şiddet uygulamak gibi davranışların ortaya çıkmasına neden olduğu belirtilmiştir (Oteri ve ark,2007; Miller, 2008). Yapılan çalışmada öğrencilerin sigara ve enerji içeceği tüketme oranı tıp fakültesi öğrencilerine göre yüksek iken, alkol tüketim oranları benzer tespit edilmiştir. Bu farklılıkların tıp fakültesi öğrencileri ile ön lisans öğrencilerinin öğrenim süreleri ve öğrenim içeriklerinin farklı olmasından kaynaklanabileceği düşünülmektedir. Yapılan çalışmada alkol ile birlikte enerji içeceği tüketme isteğinin \%13 oranında olması karar verme yetisinin azalmasından kaynaklanan davranışların ortaya çıkmasının azalması noktasında pozitif etkiye sahiptir. Çalışmaya katılan grubun yüksek oranda enerji içeceği tüketmekle birlikte günlük yaşantı içinde çay, kahve ve gazlı içecek tüketiminin yanında düşük oranlarda alkol ve sigara tükettikleri yüksek oranda egzersiz yaptıkları belirlenmiştir. Ayrıca enerji içecekleri hakkında bilgi sahibi olmamaları ve sağlık konusunda oluşturduğu riskleri tam anlamıyla bilmemeleri tüketim miktarları düşük olmasına rağmen gün içerisinde tükettikleri diğer içecek türlerinin ve miktarlarının da önemi ortaya çıkmaktadır. Çay, kahve ve soft içeceklerin içinde bulunan kafein ve şekerlerinde etkisiyle cinsiyet ve yaş faktörü göz önüne alınarak tüketim yapılması gerektiğinden ölüme kadar giden ciddi sağlık risklerinin oluşmasına sebep olacağı unutulmamalıdır.

Sonuç olarak; enerji içeceği tüketimi içindeki kafeinden dolayı düşük dozlarda alındığında genç yetişkinlerde bilişsel, zihinsel ve fiziksel performans üzerine olumlu etkileri olduğu söylenebilir. Enerji içeceğinin tüketim oranları ve etkileri konusunda literatürde çelişkili bulgular olmasından dolayı özellikle diyabet hastaları, kardiovasküler rahatsızlıkları olanlar, böbrek yetmezliği, nörolojik rahatsızlıkları olanlar ve ilaç alan hastalar enerji içeceklerindeki yüksek glisemik indeks, kafein ve diğer besin maddelerinde bulunan uyarıcılardan dolayı doktor onayı alındıktan sonra kullanması gerektiğini söyleyebiliriz. Herhangi bir sağlık problemi olmayan uyanık kalmak zorunda olan kişiler, uzun yol şoförleri, fazla enerjiye ihtiyaç duyanlar tüketim yaparken kefein oranına dikkat etmelidir. Yapılan çalışmada ön lisans öğrencilerinin enerji içecekleri hakkında bilgi seviyelerinin düşük olması ve yüksek oranda enerji içeceği tüketmeleri sebebiyle görsel medyadan enerji içecekleri ve etkileri ile ilgili destek alınabilir. Ayrıca geleceğin yetişkinleri olan tüm çocuk ve adolesanlara erken öğretim dönemlerinde enerji içeceğinin etkileri anlatılmalıdır. Bu konuda gelecekte çalışma yapacak olanların günlük olarak alınan diğer besin ve yardımcı besin ögelerini kayıt altına almaları tüm alışkanlıklar ve bilinç düzeyleri hakkında daha detaylı bilgi edinilmesine katkı sağlayacaktır.

\section{Kaynaklar}

Alford, C., Cox, H., Wescott, R. 2001. The effects of red bull energy drink on human performance and mood. Amino Acids. 21(2):139-150.

Anderson, C., Horne, J.A. 2006. A high sugar content, low caffeine drink does not alleviate sleepiness by may worsen it. Human Psychopharmacology: Clinical and Experimental, 21:299-303.

Arria, A. M., Caldeira, K. M., Kasperski, S. J., Vincent, K. B., Griffiths, R. R., O’Grady, K. E. 2011. Energy drink consumption and increased risk for alcohol dependence. Alcoholism, Clinical and Experimental Research, 35(2), 365-375.

Avc1, S., Sarikaya, R., Buyukcam, F. 2013. Death of a young man after overuse of energy drink. Am J Emerg Med. 31(1624), 3-4. 
Baum M, Weiß M. 2001. The influence of a taurine containing drink on cardiac parameters before and after exercise measured by echocardiography. Amino Acids, 20:75-82

Beaudoin, M.S., Allen, B., Mazzetti, G., Sullivan, P.J., Graham, T.E. 2012. Caffeine ingestion impairs insulin sensitivity in a dose-dependent manner in both men and women. Applied Physiology, Nutrition, and Metabolism, 38(2),140-147

Bedi, N., Dewan, P., Gupta, P. 2014. Energy drinks: Potions of illusion. Indian pediatrics.51(7):529533.

Berger, A.J., Alford, K. 2009. Cardiac arrestina young man following excess consumption of caffeinated "energydrinks". Med J Aust, 190, 41-3.

Bichler, A., Swenson, A., Harris, M.A. 2006. A combination of caffeine and taurine has no effect on short term memory but induces changes in heart rate and mean arterial blood pressure. Amino Acids, 31, 471-476.

Dasey, D. 2007. Man's heart stops after Red Bull overdose. The Sydney Morning Herald. Ağustos 19 2007, Erişim: http://www.smh.com.au/articles/2007/08/18/1186857834956.html

Dikici, S., Aydın, L.Y., Kutlucan, A., Ercan, N. 2012. Enerji içecekleri hakkında neler biliyoruz?. Dicle Tip Dergisi, 39 (4), 609-613.

Duchan, E., Patel, N.D., Feucht, C. 2010. Energy drinks: a review of use and safety for athletes. Phys Sportsmed, 38(2), 171-179.

Espinosa, J.C., Sobrino, M.F. 2015. Caffeine and headache: specific remarks. Neurologia, Erişim: http://www.ncbi.nlm.nih.gov/pubmed/25728949

European Food Safety Authority, Annual Report 2011, http://www.efsa.europa.eu/en/press/news/130306

Froiland, K., Koszewski, W., Hingst, J., Kopecky, L. 2004. Nutritional supplement use among college athletes and their sources of information. Int J Sport Nutr Exerc Metab, 14, 104-120.

Ghosh, B.G. 2015. Sports \& energy drinks: keep them separated. Nutraceuticals World. 18(8), 50-51, 09 Aralık 2015 http://web.b.ebscohost.com/ehost/pdfviewer/pdfviewer?vid=21\&sid=4200592c492d-4840-b6a2-cba2a8a8c76b\%40sessionmgr113\&hid=116

$\begin{array}{llllll}\text { Gida Tarım Hayvancılık } & \text { Bakanlığı } & \text { Erişim: } & 25 & \text { Mart } & 2016\end{array}$ http://www.baib.gov.tr/files/downloads/PageFiles/\%7B165e4680-d765-4b15-a6e6 579589d2c9ed\%7D/Files/EK1\%20Teblig\%20Taslagi.PDF

Hasselkvist, A., Johansson, A., Johansson, A.K. 2009. Dental erosion and soft drink consumption in Swedish children and adolescents and the development of a simplified erosion partial recording system. Swedish dental journal. 34(4):187-195.

Hıdıroğlu, S., Tanriover, Ö., Ünaldi S., Sulun S., Karavus, M. 2013. A survey of energy-drink consumption among medical students. J Pak Med Assoc.63, 842.

Hoffman, J.R, Kang, J., Ratamess, N.A, Hoffman, M.W, Tranchina, C.P, Faigenbaum, A.D. 2009. Examination of a high energy, pre-exercise supplement on exercise performance. J Int Soc Sports Nutr. 6:2

Ivy JL, Kammer L, Ding Z, Wang B, Bernard JR, Liao YH, Hwang J. 2009. Improved cycling timetrial performance after ingestion of a caffeine energy drink. Int J Sport Nutr Exerc Metab. 19(1):61-78.

Kohler, M., Pavy, A., Van Den Heuvel C. 2006. The effects of chewing versus caffeine on alertness, cognitive performance and cardiac autonomic activity during sleep deprivation. Journal of Sleep Research, 15, 358-368 

BİR MESLEK YÜKSEKOKULU ÖRNEĞİ

Kreider, R.B, Wilborn, C.D, Taylor ,L., Campbell, B., Almada, A.L., Collins, R., Cooke, M., Earnest, C.P., Greenwood, M., \&Kalman, D.S. 2010. ISSN exercise \& sport nutrition review: research \& recommendations. $J$ Int Soc Sports Nutr, 7,7.

Kristiansen, M., Levy-Milne, R., Barr, S., Flint, A. 2005. Dietary supplement use by varsity athletes at a canadian university. Int $J$ Sport Nutr Exerc Metab, 15, 195-210

Lee, S.J., Hudson, R., Kilpatrick, K., Graham, T.E., Ross, R. 2005. Caffeine ingestion is associated with reductions in glucose uptake independent of obesity and Type 2 diabetes before and after exercise training. Diabetes Care, 28, 566-572.

Loyacano, S.L. 2000. The Relationship between caffeine consumption and study habits Erişim: 09 Aralı 2015, [Clearinghousehttp://www.webclearinghouse.net/volume/3/LOYACANO TheRelatio.php

Malinauskas, B.M., Aeby, V.G., Overton, R.F., Carpenter-Aeby, T., Barber-Heidal, K. 2007. A survey of energy drink consumption patterns among college students. Nutrition Journal, 6, 35 .

Miller, K.E. 2008. Energy drinks, race, and problem behaviors among college students. Journal of Adolescent Health, 43(5), 490-497.

Oteri, A., Salvo, F., Caputi, A., Calapai, G. 2007. Intake of energy drinks in association with alcoholic beverages in a cohort of students of the school of medicine of the university of messina. Alcohol Clin Exp Res, 31(10),1677-1681.

Perez, L.A., Salinero, J.J., Abian, V.J., Valades, D., Lara, B., Hernandez, C., Areces, F., González, C., Del, C.J. 2015. Caffeinated Energy Drinks Improve Volleyball Performance in Elite Female Players. Med Sci Sports Exerc. 47(4):850-6.

Reissig, C.J., Strain, E.C., Griffiths, R.R. 2009. Caffeinated energy drinks a growing problem. Drug Alcohol Depend, 99(1-3), 1-10.

Reyner, L.A., Horne, J.A. 2002. Efficacy of a "functional energy drink" in counteracting driver sleepiness. Physiol Behav. 75:331-335

Riesenhuber, A., Boehm, M., Posch, M., Aufricht, C. 2006. Diuretic potential of energy drinks. Amino Acids, 31:81-83

Roberts, M.D, Dalbo, V.J, Hassell, S.E., Stout, J.R., Kerksick, C.M. 2008. Efficacy and safety of a popular thermogenic drink after 28 days of ingestion. J Int Soc Sports Nutr, 5:19.

Rodriguez, N.R, Di Marco N.M, Langley, S. 2009. American college of sports medicine position stand. nutrition and athletic performance. Med Sci Sports Exerc. 41,709-731

Scholey, A.B., Kennedy, D.O. 2003. Cognitive and physiological effects of an "energy drink": an evaluation of the whole drink and of glucose, caffeine and herbal flavouring fractions, Psychopharmacology, 176: 320-330

Schubert, M.M., Astorino, T.A., Azevedo, JL Jr. 2013. The effects of caffeinated "energy shots" on time trial performance. Nutrients. (5), 2062-2075.

Seifert, S.M., Schaechter, J.L., Hershorin, E.R., Lipshultz, S.E. 2011. Health effects of energy drinks on children, adolescents, and young adults. Pediatrics. 127:511-28.

Shelon C S Pinto., Matheus C Bandeca., Carolina N.S.., Cavassim, R., Alvaro H Borges, José E C Sampaio Erosive. 2013. Potential of energy drinks on the dentine surface .BMC Research Notes, $6: 67$

Smit H.J, Rogers P.J. 2000. Effects of low doses of caffeine on cognitive performance, mood and thirst in low and higher caffeine consumers. Psychopharmacology, 152, 167-173.

Smit, H.J., Cotton, J.R., Hughes, S.C., Rogers, P.J. 2004. Mood and cognitive performance effects of 
"energy" drink constituents: caffeine, glucose and carbonation. Nutritional Neuroscience, 7,127139.

Stout, J., Moon, J., Tobkin, S., Lockwood, C., Smith, A., Graef, J., Kendall, K., Beck, T., Cramer, J. 2008. Pre-workout consumption of Celsius(R) enhances the benefits of chronic exercise on body composition and cardiorespiratory fitness. J Int Soc Sports Nutr. 5:P8.

Worthley, M.I., Prabhu, A., Sciscio, P.D., Schultz, C., Sanders, P., Willoughby, S.R. 2010. Detrimental effects of energy drink consumption on platelet and endothelial function. Am J Med.123(2):184-187.

Yunusa I, Ahmed IM. 2011. Energy drinks: composition and health benefits. Bayero J Pure Applied Sci. 4:186-91.

Zucconi, S., Volpato, C., Adinolfi, F., Gandini E., Loi, A., Fioriti, L. 2013. Gather- ing consumption dataon specific consumer groups of energy drinks. Parma: Supporting Publications. 